\title{
GREEN TRANSPORT - THE USAGE OF ELECTRIC SCOOTER FOR PUBLIC TRANSPORT IN TOWNS
}

\author{
Anton Vorina ${ }^{1}$ \\ Gabi Čakš² \\ Jelka Županec ${ }^{3}$
}

DOI: https://doi.org/10.31410/LIMEN.2019.37

\begin{abstract}
In recent years, we are seeing more and more scooters powered by an electric motor on the roads. They flooded the streets of every city and town. They have become extremely popular among children and adults. Their multiplicity raises many questions, comparisons, doubts and challenges. The aim of the paper is to answer the four research questions: 1. How long does one rechargeable scooter battery last? 2. Which (European) countries prohibit the use of electric scooters? 3. Will electric roadways reduce traffic jams? 4. What are the rental possibilities of electric scooters in Slovenia? The data will be obtained through desktop research. For collecting data, we will use the internet resources. We found out that in Slovenia there still exist unspecified regulations for driving/using the electric scooter. On the other hand, in Germany, the users of electric scooters should respect very strict state regulations for driving the electric scooter.
\end{abstract}

Keywords: Green transport, Electrical scooter, Logistic.

\section{INTRODUCTION}

$\mathrm{T}$ oday's society has worked closely with modern technology and devices. Without these inventions, we can no longer imagine our daily life. We are surrounded by them, both privately and business-wise. Today's society requires fast, simple and an effective technology with a low-cost budget. Riding an electric scooter has the advantage of riding for all population - both young and old. However, this advantage may present a problem for us as it can become very dangerous in the surrounding area when we remain in the carriageway area. We mostly ride it on pavements and because electric scooters are very quiet, they can be deadly dangerous to pedestrians.

There are not many articles on the subject, so we used the literature of recent times (mostly from 2018 to 2019).

The objective of the research is to answer the seven research questions:

1. How long does one rechargeable battery last?

2. Which (European) countries prohibit the use of electric scooters?

3. Will electric roadways reduce traffic jams?

4. What are the rental possibilities of electric scooters in Slovenia?

Celje School of Economics, Vocational College, Mariborska 2, 3000 Celje, Slovenia

VIZ II. OŠ Rogaška Slatina, Ulica Kozjanskega odreda 4, 3250 Rogaška Slatina, Slovenia

Osnovna šola Frana Metelka Škocjan, Škocjan 51, 8275 Škocjan, Slovenia 


\section{AN ELECTRIC SCOOTER}

\subsection{The history of electric scooters}

Just a short walk through the city gives you the immediate impression of the electric scooter which is currently one of the most popular means of transportation for urban centers. They represent a fast-growing segment that has experienced a real blast in the last year or two. Greener use and their convenience are driving the market to grow at an extraordinary pace worldwide. However, most people do not even imagine that the history of electric scooters dates back to 1895. At that time, the first patents were filed for an electric powered personal transport vehicle. The first electric scooters did not have much in common with today's representatives, but it is interesting to know where their history comes from. One of the most important factors for the rapid commercial rise of electric bikes and electric scooters are modern batteries. Even two decades ago, the electric scooters weighed 113 pounds. According to records, the first electric vehicle patent was filed in 1895 by inventor Ogden Bolton of Ohio, in the United States. In 1896, the bicycle manufacturer Humber introduced the first commercial electric bicycle. This e-bike was powered by a series of batteries that provided power to the front-wheel drive. The first scooter, which was also reminiscent of today's representatives, was introduced in 1915 by Autoped. The latter's propulsion was fueled, and yet it was one of the first widespread motor-powered scooters. The electric scooters become popular with the New York Police because police officers used them for their city check trips and controls [1].

\subsection{An electric scooter- the solution for traffic jams?}

The latter have become extremely popular in recent months, especially in Ljubljana, Slovenia where there are more and more quiet but fast electric vehicles rolling between pedestrians, cyclists and also cars. The popularity of such vehicles is also evidenced by the offer made by many supermarkets and brands of such vehicles, especially the one with a lower price. Electric scooters are offered by oil traders and are available in shopping schemes and discount catalogues. Although there are many offers on the market where one can buy or rent an electric scooter in Slovenia, the market is even richer abroad, especially in bigger foreign cities and urban centres, where rental systems for electric scooters are enriched by the dealers. It is clear that all major players in the mobility market, including Uber, which offers scooter rentals in the USA cities, through its mobile app, have taken on an extremely lucrative business. The one who closely follows the development in this field will certainly read that the scooter sharing market has already claimed the first casualties - both in the business of electric cleaner providers (some have already been canceled) and among users - due to accidents and injuries. Nevertheless, electric scooters (and electric bikes) are already one of the given solutions to the congestion and congestion of large urban centers - both in the context of a cleaner environment and in addressing congested public transport systems and reducing the number of cars on the streets. It will be shown in the future if they are really effective [2].

\subsection{An equipment and the battery maintenance}

The choice of electric scooters is already extremely wide, so it is advisable to narrow it down to some models that are appropriate in weight and size, in handlebar height, less in terms of design and appearance, although more and more brands offer scissors separately for women and men. Pay attention to the way and the quality of the workmanship, and like the wheels, the 
more expensive models are said to be made of higher quality, of higher quality materials and lighter, especially those of carbon fiber. Three-wheelers are easier to handle, with lean weight and tilt control. The models also differ in braking modes: at higher speeds and when driving downwards, the rear brake is applied by pushing the rear wheel fender, while many models of electric scooters have brake levers already in place. The wheels are plastic, silicone or inflatable, again depending on the model and price range. For the more expensive models, make sure they are equipped with smooth rotary bearings. E-scooters are powered by a variety of batteries, from classic lead ones, which are also the heaviest, to the more modern and lighter lithium-ion ones. They can be installed in different places. More modern scooters come with an integrated battery. Good batteries should last from five hundred to even two thousand and more charge cycles with care. They last from 2-3 hours to five hours or more. The lithium batteries do not have to be fully charged after each run, and it is sufficient to charge up to $80 \%$ of capacity. Do not discharge it completely, because when the battery reaches the minimum voltage, it loses a bit of its capacity permanently [3].

\subsection{The advantages and disadvantages of electric scooters}

The advantages of E-scooters are that they are lightweight, portable (you can take it with you to work), they provide a faster travel speed than normal, they are powered by legs, they achieve double walking speed, they are easy to (re)charge, they are foldable, which means that they do not take up much space.

Among the disadvantages, or even the possible dangers, are considered the relative instability of the vehicle itself, inaudibility at high speed, which is especially evident on pedestrian surfaces, a poor equipment, a lack of adequate equipment such as lights, and the same applies to users who are much less secured/safe similar as riding by bicycle or moped [4].

\subsection{Accidents with electric scooters in Slovenia and in Europe}

This year (2019), 220 injured E-scooters users were treated at UKC (General Hospital in Ljubljana) Slovenia. There were tremendous bruises, wrist fractures and severe head damages [5].

Many fatalities abroad were reported. The exact number of casualties is unknown. The case of the victim in Paris claims: The accident occurred at midnight (the motorcycle hit the e-scooter) on the A86 motorway on Friday, four kilometers from Versailles, southwest of Paris. Police said it was unclear whether the e-scooter driver wore a helmet or not, whether there were lights on (visible) or not. The motorist remains in serious condition at the hospital. Police found his engine 400 feet away from the point of the crash. In 2018, 5 deaths in France and 3 in Spain were dealt with [6].

\subsection{The future of the use of electric scooters}

The start- up company MikMik in the Slovenian market exclusively represents the rental system (Figure 1) of electric scooters without charging stations. Using the mobile application, the user finds the closest scenery on the map, which, when completed, can easily park at the desired final destination, subject to road traffic regulations. The system, unlike other transport providers, operates without a main terminal and stops. After driving, he can leave the scroll anywhere he wants, and parking rules are listed in the app and also locked in the app. The next user can find the hidden way via the built-in GPS tracker. The scooter can travel up to 25 kilometers with a 
full battery and can reach up to 15 kilometers per hour. This is a new dimension of e-mobility in Slovenia, with which MikMik wants to reduce its dependence on cars and leave the next generations with a cleaner and healthier planet. For urban life, this form of transportation has many advantages. It provides affordable urban transport and quick and easy mobility to micro-locations. Therefore, they want to provide cities with new efficient mobility options and complement public transport systems while minimizing unwanted side effects [7].

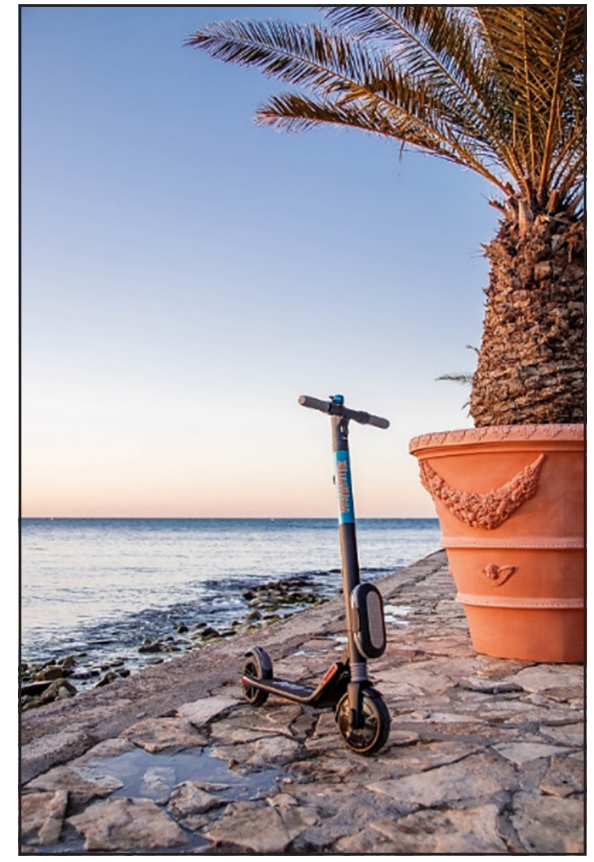

Figure 1: Rent e-scooter provides by MikMik company

Source: [7].

Electric scooters are a major shift in transportation and traffic market. Something that initially looked like a toy will shape the future of cities, our behavior and technology. According to various authors, a new level of personal mobility is coming to reality. They represent a great competition to big companies like Uber, Bird, Lime. The possibility is that electric scooters will start transporting billions of people and will probably soon replace public transport [8].

\section{ANSWER TO RESEARCH QUESTIONS}

The answers to research questions are given below.

\subsection{How long does one rechargeable battery last?}

We found out that batteries of an average e-scooter can last from 2-3 hours of driving; better and more expensive scooters' batteries last up to 5 hours or more. The batteries do not need to be fully charged after each run; it is sufficient to charge up to its $80 \%$ of capacity.

\subsection{Which (European) countries prohibit the use of electric scooters?}

E-scooters are banned in Italy, Milan. E-scooter users were banned from pavements in France this September. E-scooter driving in the UK is prohibited, except on specific playgrounds. Germany is the last country to turn on the green light for E-scooters, both on 
the road and on the pavements. We have found that there is no appropriate traffic law that permits the use of the E-scooter in road transport in Slovenia. E-scooter drivers must be up to $5 \mathrm{~km} / \mathrm{h}$ (just like pedestrian walking speed), otherwise, the driver is fined 500 euros.

\subsection{Will electric roadways reduce traffic jams?}

E-scooters are being used by more and more people, especially for short distances. If we have a store close by, we can easily use the E-scooter, without spending a lot of time looking for a free parking space, as we can fold and take the E-scooter with us, or leave it in front of the store. This is one of the many factors that could or will reduce the traffic jams on the road. However, E-scooter drivers ride on pavements and areas of common traffic and this creates a traffic jam.

\subsection{What are the rental possibilities of electric scooters in Slovenia?}

We note that there is a company MikMik in Slovenia, located on the coast, which rents electric scooters, without charging stations. The E-scooter rental system is available through their mobile application. This is a new dimension of E-mobility, with which the company wants to reduce its dependence on passenger cars and thus reduce traffic jams, especially in urban centers.

\section{CONCLUSION}

The article describes the basic characteristics of electric scooters, their advantages and disadvantages, as well as the dangers of using them. Some electric scooters are foldable and can be taken with a person to work. They are virtually inaudible, so they can be very dangerous for pedestrians or passers-by, as they reach speeds of $25 \mathrm{~km} / \mathrm{h}$ to $35 \mathrm{~km} / \mathrm{h}$. We believe that E-scooter drivers should also wear a helmet. There is a large increase in the use of electric scooters in Slovenia, especially around the cities, so MikMik has decided to allow the rental of electric scooters on the coast, although they are prohibited by law. Let's look at the current law - an electric scooter is forbidden for the simple reason - because these are special vehicles that are powered by an engine and exceed pedestrian speed, as laid down in Article 97, paragraph 5 of the Road Traffic Rules Act. Because e-scooters do not belong to bicycles, scooters or mopeds, they are therefore prohibited from running on cycle paths or on pavements. Of course, users do not adhere to this, nor are they punished by the state, and the number of injuries is increasing [9].

We did not find out where electric scooters can be recharged in public places (like electric cars can be stuffed). We believe that it will be necessary to clearly state in Slovenia the traffic legislation regarding the use of electric scooters on roads and bike lanes, as they did in Germany for a year. In Germany, from March 2019, the following regulations apply to electric scooters:

- Minimum age: The minimum age for e-scooter rides is 14 years, with many rental companies requiring a minimum age of 18 years.

- Driver's license: A moped driver's license is required to use e-scooters whose speed exceeds $6 \mathrm{~km} / \mathrm{h}$. If you have a driver's license for a scooter, motorcycle or car, the requirements are met automatically. For e-scooters with a maximum speed of up to 6 $\mathrm{km} / \mathrm{h}$, a driver's license is not required. Please note that you cannot drive e-vehicles on public roads without a valid driving license. Private reasons are excluded as road regulations do not apply here. 
- Cycling route or road: E-skiers are allowed to ride both the cycle route and the road. E-scooter users/ drivers are not allowed to drive on the footpath.

- Insurance and Helmet: The e-scooter does not require a helmet, license plate or driver's license, but is an obligation to insure liability. However, it is advisable to wear a helmet for your own safety.

- Road safety: E-scooters have to have, like a bicycle, a headlight and a tail light, a bell and brakes [10].

Further research should explore the situation in other European countries and possibly include the police as a source of information and existing users of electrical scaffolding.

\section{REFERENCES}

[1] Zgodovina električnih skirojev. (2019). Acquired 10. 9. 2019 from the website http://www. zdravobitje.si/zgodovina-elektricnih-skirojev/.

[2] Na cestah vse več električnih koles in skirojev. (2019). Acquired 10. 10. 2019 from the website https://www.amzs.si/motorevija/mobilnost/promet/2019-05-05-na-cestah-vse-vec-elektricnih-koles-in-skirojev.

[3] Električni skiro je novi kralj ceste. (2019). Acquired 12. 11. 2019 from the website https:// siol.net/sportal/rekreacija/elektricni-skiro-je-novi-kralj-ceste-505356

[4] Švarc, Artur. (2019). Prevozno sredstvo prihodnosti ali grožnja? Acquired 20. 11. 2019 from the website http://www.avtomanija.com/default.asp?rb=19\&id=77.

[5] Tako hude so poškodbe voznikov skiroja. (2019). Acquired 15. 11. 2019 from the website https://www.zurnal24.si/slovenija/tako-hude-so-poskodbe-voznikov-skiroja-333573.

[6] Voznik električnega skiroja se je smrtno ponesrečil med vožnjo po avtocesti. (2019). Acquired 20. 11. 2019 from the website https://www.rtvslo.si/svet/voznik-elektricnega-skiroja-se-je-smrtno-ponesrecil-med-voznjo-po-avtocesti/496721.

[7] Najemi električni skiro in se zapelji ob obali. (2019). Acquired 20. 11. 2019 from the website https://www.aktivni.si/ostali-sporti/najemi-elektricni-skiro/.

[8] Podgayetsky, Yev. (2018). What's the future of electric scooters? 18-point roadmap. Acquired 20. 11. 2019 from the website https://medium.com/swlh/whats-the-future-of-electric-scooters-18-point-roadmap-14e1f3f9e00d.

[9] Promet - Električni skiroji. (2019). Acquired 18. 11. 2019 from the website http://www. avtomanija.com/default.asp?rb=19\&id=77.

[10] Eggerth, Tanja. (2019). E-Scooter: Straßenzulassung in Deutschland - alle Infos. Acquired 15. 11. 2019 from the website https://praxistipps.chip.de/e-scooter-strassenzulassung-in-deutschland-alle-infos_109520. 